IJTC

Ilomata International Journal of Tax \& Accounting

P-ISSN: 2714-9838; E-ISSN: 2714-9846

Vol. 1 No. 2 March 2020 Pp : 89-102

https://www.ilomata.org/index.php/ijtc

\title{
How to Align Management Commitments to the Successful Implementation of Management Accounting Information Systems in Manager Decision Making
}

\author{
${ }^{1}$ Lesi Hertati, ${ }^{2}$ Otniel Safkaur, ${ }^{3}$ Aoron M. Simanjuntak. \\ ${ }^{1}$ Departement of Accounting, STIE Rahmaniyah - Indonesia \\ ${ }^{2.3}$ Departement of Accounting, Faculty of Economics and Business Universitas Cendrawasih, \\ Sorong Papua Indonesia. \\ hertatilesi@yahoo.co.id
}

Submitted : Jan 3th 2020 Revised : Feb $18^{\text {th }} 2020$ Published : March $30^{\text {th }} 2020$

\begin{abstract}
ABSTRAK
This study investigates the effect of management commitment on the successful application of management accounting information systems and their implications for manager decision making. The unit of analysis in this study is the functional unit in Small and Medium Enterprises in Indonesia. This research also implies that the responsiveness of organizations to the successful implementation of management accounting information systems is very important not only for internal and external but for the organization itself in building a sustainable corporate image, and successes that enhance organizational reputation and manager's understanding of financial and non-financial information. finance is in line with the increasing commitment of the management in the company. Furthermore, this study states that management commitment influences the success of management accounting information systems and their implications for manager decision making. The Lisrel SEM modeling results confirm that management's commitment to the success of management accounting information systems and their implications for managerial decision making have a significant effect.
\end{abstract}

Keywords: Management Commitment, Management Accounting Information Systems, Manager Decision Making

\section{INTRODUCTION}

Die industry era 4.0 the government launched the E-Smart program of small and medium industry programs to expand the market share of small and medium industries through online promotional information. Furthermore, Hertati (2019) states that E-Smart small and medium industries are small and medium industry database systems that provide information on industry profiles, central products that are integrated with various existing marketplaces. Furthermore Susanto (2016) states that information is the glue of the organization, the better the quality of information, the better the communication within the organization and the better the integrity of the organization. The value of an information depends on the quality of the information presented (Susanto, 2016).

Quality information according to Mc Leod and Schell (2007: 65) must have characteristics relevant, accurate, timely and complete. Hertati (2016) states that information can be said to be relevant if the information contained therein can influence users' decisions by helping them evaluate past or present events, and predict the future, and confirm or correct the results of their evaluations in the past. The importance of quality information in decision making as stated by Laudon and Laudon (2008: 13) that quality information can be used for decision making where the results are the right decision, better allocation of resources and response times to provide benefits and reduce costs. 
How to Align Management Commitments to the Successful Implementation of Management Accounting Information Systems in Manager Decision Making

Hertati, Safkaur, Simanjuntak

Seeing the role of information that is so high for the organization, the organization becomes very dependent on the information system (Susanto, 2008: 11). Then Hall (2011: 7) states that the information system is part of the information system that is a set of formal procedures where data is collected, processed into information and distributed to users. Furthermore, McLeod \& Schell (2007: 19) states that the role of information systems prioritizes data into information and emphasizes administrative work into problem-solving activities, then information systems are developed specifically to assist managers in the decision making process. Furthermore, Gelinas and Dull (2008: 11) state that to process business activities and provide information for management in making decisions, the information systems used by companies must be designed, implemented and operated effectively). Regarding the importance of an adequate information system Intermezzo (2019) states that small and medium business entrepreneurs have difficulty in increasing their business levels. The business they run does not develop and the turnover obtained does not increase. At present, the number of small and medium business products that can penetrate the international market is still very small. One reason for the difficulty of small and medium business products to compete in foreign markets is the low competitiveness of products. Moreover, if related to the price offered, Indonesian SME products are still far from the quality offered by foreign products(Meilani \& Pandoyo, 2019).

According to Laudon and Laudon (2008: 9) that companies that invest more in their information systems specifically to achieve six strategic business objectives: operational excellence; new products, services, and business models; customer and supplier relations; better decision making; competitive advantage; and business continuity. Management accounting information systems provide information, both financial and non-financial information to managers and employees of the organization because the information needed by decision-makers includes financial information and non-financial information such as product quality, customer satisfaction and service response levels (Atkinson et al. , 2009: 3). The same thing was conveyed by Taicu (2009) which stated that management accounting information systems are the main providers of information needed by management to make decisions in the company.

The importance of an adequate management accounting information system is in line with the opinion of Mitchell et al., (2000) which states that a management accounting information system is needed that provides information to management regarding pricing, costs, and cash flow and to assist the decision making process, operational considerations and programs long-term strategy in a dynamic and competitive environment. The phenomenon that occurs is related to the accounting information system difficulties in product innovation, by applying a new formula or production method. Do not open up and join the training held by the Ministry of Cooperatives and small and medium businesses and companies that give special attention to small and medium businesses. Small and medium businesses are not active in analyzing competitors' products.

Sajady (2008: 10) that the function of management accounting information systems provides important information to help managers control their activities, and reduce environmental uncertainty, so that it is expected to help the company towards achieving its goals successfully. The phenomenon of the importance of an adequate management accounting information system related to the unavailability of accounting information as stated by, Intermezzo (2019) states that many are not aware that manual bookkeeping is a small and medium problem. Manual bookkeeping is prone to loss, damage and even recap errors. Thus, entrepreneurs cannot analyze the sales results appropriately. For example: if the sales report on a certain day suddenly disappears, then the overall sales report will be in shambles. A good accounting is the key to an adequate business evaluation. With good bookkeeping, you can 
How to Align Management Commitments to the Successful Implementation of Management Accounting Information Systems in Manager Decision Making

Hertati, Safkaur, Simanjuntak

analyze your business sales more precisely as a consideration for making further decisions. In addition, good bookkeeping is also a mandatory requirement for all entrepreneurs who want to borrow business capital from banks. So, the problem of bad business bookkeeping, then certainly difficulties in getting business capital loans from banks.

According to Susanto (2008: 17) management accounting information systems are information systems used by companies which include financial and non-financial information. In order to obtain adequate information both financial and non-financial information, a management accounting information system is needed as stated by Hansen and Mowen (2007: 8) that a management accounting information system is a process that explains activities such as collecting, measuring, storing, analyzing, reporting, and managing information (The management accounting information system is processes, there are described by activities such as collecting, measuring, storing, analizing, reporting and managing information).

Hansen and Mowen (2007: 5) states that management accounting information systems have three general objectives, namely to: 1) Provide information for the cost of services, products, and other objects desired by management. 2) Provide information for planning, controlling, evaluating, and continuously improving. 3) Provide information for decision making. According to Horngren, et al. (2017) that decision making is choosing from among an alternative set of programs of actions designed to achieve several objectives that require accounting information. Furthermore according to Harris (2009: 4) states that decision making is a process of identifying as many alternatives as possible and choosing one alternative that has a probability of success or effectiveness in accordance with the goals, desires, lifestyle, and desired values. Decision making is a fundamental aspect of the management function and management decision making is a major role of management (Teale, et.al., 2003: 10). The same thing was conveyed by J. Salusu (1996: 46) who stated that decision making plays a role in every organization, including the principles of the organization that will guarantee the right decision is taken, as well as must include the principles that will ensure effective action.

According to Laudon \& Laudon (2008: 12) that not a few company managers run business activities without a clear source of information and almost never have the right information at the right time for decision making, so more trust in predictions, guesses and luck. Yet according to Robbins and A Judge (2008: 189) every manager should behave to maximize or optimize certain results through the decision making process. Another phenomenon that has caused losses to the state due to failure in decision making occurs in the case of banking service companies, namely the Century Bank case.

Chairman of the House Commission XI, Ahmad Zawawi (2009) asked BPK to evaluate and audit Century Bank regarding the failure of the decision-making process that was detrimental to the state. Failure to make such a decision is not only because it was taken without making a detailed assessment of all information, but also because of abuse of authority by Bank Indonesia. A similar statement was made by Abraham Samad as the Chairperson of the Corruption Eradication Commission (2013) which stated that the Corruption Eradication Commission had indicated a criminal act of corruption in the Century Bank case because there had been an incorrect decision-making, due to inaccurate data giving. Laudon and Laudon (2008: 13) state that problem solving will not be effective without accurate information. Decision making has an important meaning for the back and forth of an organization, especially because the future of an organization is largely determined by decision making

The important role of management commitment was conveyed by Englund and Buchero (2006) that the relationship between management commitment and information system development is the participation of top management and middle management in the formulation of objectives and 
How to Align Management Commitments to the Successful Implementation of Management Accounting Information Systems in Manager Decision Making

Hertati, Safkaur, Simanjuntak

clarifying the development of information systems, work commitments in documenting work plans for accountability in directing business, approving, measure, supporting activities from the beginning to the end of the development project as a form of active role of top management and middle management. Understanding commitment as a relationship between the actor (actor) with the entity (entity) stated by Abrahamsson and Iivari (2002). A similar opinion was conveyed by Meyer and Herscovitch (2001: 31) which states that commitment is a force that binds an individual to an action that is relevant to one or more targets. According to Cooper (2006) that management commitment as a form of involvement in behavior and maintaining behavior to achieve a goal. Furthermore, management commitment must be directed into a strong desire to improve the quality of the entire business of the company as stated by Yousaf (2006) that: In line with the orientation of values and organizational goals, Malthis and Jackson (2008: 21) states that organizational culture is a form of values and confidence in an organization.

Luthan (2006: 45) states that organizational culture is the norms and values that guide the behavior of organizational members. Each member will behave according to a culture apply, in order to be accepted by the environment. Kreitner and Kinichi (2001: 68) state that organizational culture is a shared group, implicitly that groups hold and determine how they perceive, think, and react to various conditions. Furthermore according to Robbins and A Judge (2008: 258) organizational culture is related to how employees understand the cultural characteristics of an organization where organizational culture seeks to measure how employees perceive their organization so that it is expected that individuals who have different backgrounds or are at different levels in organizations will understand organizational culture with a similar understanding.

Based on the above phenomenon, it can be concluded that the picture is related to the following phenomenon: 1) It is not uncommon for the information generated to require further processing so that information can be used as needed up to date. 2) Difficulties in tracking prospective customer information and providing maximum service support to customers. 3) Lack of information technology used requires interface facilities so that information can be integrated. 4) There are difficulties in determining certain financial items accurately and up to date 5) Sometimes have difficulty in determining, including because it is not supported by an adequate database so it is difficult to determine an effective sales and marketing system. 6) It is not uncommon mistakes in decision making at the level of line managers, because decisions are not supported by adequate information and analysis, such as the occurrence of decision outcomes that harm the company, 7) There is a missed communication in the decision making process that results in suboptimal decisions made because lack of good coordination between line managers, such as failure to communicate the number and type of facilities that must be prepared in a particular event or activity. 8) There are times when the decision making process does not go through the process of selecting the best alternative, such as selecting a vendor providing a product or service. 9) Lack of good cooperation as teamwork often causes losses for companies 10) Lack of top management participation in overseeing and directing line managers in disseminating corporate goals and programs that are currently and will be carried out.

Chalk (2008: 3) that management commitment is a leadership style in which managers and subordinates participate together in achieving work goals, determine the level of authority, and clarify performance commitments. (Management by commitment is a style of leadership where both the manager and subordinate participate jointly in the establishment of work objectives, define authority level, and clarify performance commitment) Furthermore Wood (1996: 35) states that the management commitment model as a management model that aims to bring up commitment, so that individual behavior is more independent not because it is controlled by external sanctions or pressures, and 
How to Align Management Commitments to the Successful Implementation of Management Accounting Information Systems in Manager Decision Making

Hertati, Safkaur, Simanjuntak

relationships within the organization are based on a high level of trust. The failure in achieving the company's goals related to management commitment as stated by Abrahamsson (2000) explains that one of the causes of failure in company activities including the software development process is management commitment which usually includes aspects of depth, focus and terms where these three aspects are psychological aspects that are can be divided into three different forms of commitment, namely: affective, normative and continuance commitment Based on the above study, it can be said that management commitment can be measured using: (Abrahamson and Jokela (2000), Wood (1996), Cooper (2006), Meyer (1997), Meyer et al. (2002))

1) Affective Commitment (I want to is a feeling of love for an organization that raises the willingness to stay and foster social relations and appreciate the value of relationships with the organization because it has become a member of the organization.

2) Continuance Commitment (I need to) is the level to which employees believe and accept organizational goals, as well as the desire to stay together or leave the company is ultimately reflected in employee absence and turnover rates.

3) Normative Commitment (I ought to) is a feeling that requires to survive in the organization due to obligations and responsibilities to the organization based on consideration of norms, values and beliefs of employees.

Ashfaq (2007: 12) states that management commitment in addition to providing adequate resources must also be actively involved in the development process. Another statement that supports the importance of management commitment in the successful implementation of management accounting information systems is Chen's statement (2001) which states that management commitment is not only limited on granting the blessing of the application of the information system but must continue until completion. Management's commitment implies that they are willing to spend a significant amount of time leading and supervising the team implementing the system. According to Abrahamsson (2000) without management commitment, most initiatives in developing information systems will fail and the results will not reach far. Hertati (2016) states that many studies show the importance of management support for the successful implementation of information systems, including the successful application of management accounting information systems.

The importance of a manager having a commitment to the implementation of the program including the application of management accounting information systems as stated by Brah and Rao, (2002) that the greater a person's commitment to his company, the greater the consistency of the person's behavior and attitudes towards organizational goals. These signals need to be spread throughout the organization, so that all members of the organization feel a commitment to the implementation of the program. Furthermore Larsen (2003) states that the level of commitment possessed by managers and employees can encourage the successful application of information systems in the company, because the attachment and loyalty of an employee to the company will encourage them to always work in various situations in the company. Other research results that support the influence of management commitment to the successful implementation of management accounting information systems are the results of research conducted by Bhanu et al. (2004), which states that: top management support is an important factor for the success of key organizational activities. These results form a framework for understanding the impact of top management support on the management accounting information system function. Furthermore Esteves et al (2002) stated that the component of management commitment in implementing the enterprice resources planning system is affective commitment related to the involvement of top management in entering into the price of 
How to Align Management Commitments to the Successful Implementation of Management Accounting Information Systems in Manager Decision Making

Hertati, Safkaur, Simanjuntak

resource planning project activities, because they show their identification with the project through participation in various project events that shown that they share the value of the project. Then Hertati (2016) states that normative commitment is related to the obligation to remain in company activities until completion. Ongoing commitments are related to costs associated with leaving or leaving projects and organizations in some cases.

The results of this study are in line with the results of research by Kirmiz1 and Orkun (2009) which states that the influence of affective commitment is higher among IT professionals than continuance commitment and normative commitment. Normative commitment is at the lowest level. IT professionals work in organizations because they want to, rather than they need or are forced by moral obligations. The importance of management support as a very important factor in the implementation of information systems is also supported by the results of research by Sharma and Yetton (2003) which states that management support is considered an important factor in the successful implementation of information system innovation. Thus the discussion with research conducted by Pabedinskaite (2010) which states that: Support top management. This is one of the most significant determinants of the successful implementation of enterprise system resource planning in an organization. Based on the theories as concepts in this study mentioned above and some of the results of research that support these theories, based on this premise, it can be said that management commitment influence the successful application of management accounting information systems.

Hypothesis1: Management's commitment influences the successful on of management accounting information systems.

This success model is a simple model but is considered quite valid by researchers. The DeLone and McLean (1992) model is a model based on theoretical and empirical studies of information systems created by researchers in the 1970s and 1980s. The understanding of management accounting information systems according to Hansen and Mowen (2007: 8) is a process that describes activities such as collecting, measuring, storing, analyzing, reporting, and managing information (The management accounting information system is processes, there are described by activities such as collecting, measuring, storing, analizing, reporting and managing information). Management accounting information systems according to Horngren, Sundem and Stratton (2011) are stated as follows Management accounting information system is the process of identifying, measuring, accumulating, analyzing, preparing, interpreting and communicating information that can help managers meet organizational goals. Similar delivered by Mitchell and Smith (2000) states understanding management accounting information systems is a management accounting information system is the process of identifying, measuring, accumulating, analyzing, preparing, interpreting and communicating financial information used by management to plan, evaluate and control an organization and to ensure and account for the use of resources). According to Susanto (2008: 17) management accounting information systems are information systems used by companies which include financial and nonfinancial information. Chenhall (1986) states that there are four characteristic dimensions of management accounting information systems, namely:

1) Scope of information system is The scope of accounting information encompasses its range, quantitative measurement and time period. Thus, the expressions of various external factors, mostly non-economic, should dominate in information management. Moreover, in the context of information management, the possibilities of future events and their prediction should be estimated.

2) Timelines of management accounting information is Accounting timeliness is defined by the time required to present the information (since it has been ordered) and the frequency of the presentation 
How to Align Management Commitments to the Successful Implementation of Management Accounting Information Systems in Manager Decision Making

Hertati, Safkaur, Simanjuntak

(periodical reports). Timeliness of information increases the management accounting possibilities to inform about the latest events and forwards managerialdecisions.

3) Aggregation management accounting may provide aggregated information in various ways: consummately raw primary data, aggregated with regard to time or goal. That might be aggregated data with regard to functional subdivisions, responsibility centers, year, quarter, month, and week information. In the same way the information is aggregated to provide for particular decision making.

4) Integrative information is Integrative information is one of the most important aspects of the organization is the coordination of activities of its various subdivisions. To help managers, management accounting should provide them with information on how purposive activities' indicators are influenced by the interrelations of various departments. In the management accounting system there should be information on how decisions in one area might affect the results of the performance of the whole department.

Santrock (2008: 12) states that decision making is a thought in which individuals evaluate various choices and decide on the choices of the many choices. This statement is supported by Jackson, Sawyers and Jenkin (2009) stating that decision making is the process of identifying different actions and choosing one decision that is right for a particular situation). The same thing was conveyed by Hansen and Mowen (2006) who stated that "Decision making is the process of choosing among. competing alternatives (decision making is the process of choosing among competitive alternatives). Harrison in Teale et al. (2003: 6) states the definition of decision making is decision making is when, in an ongoing process for evaluating alternatives to meet objectives, where expectations about certain actions by decision makers to choose that actions that are most likely to be expected to achieve goals).

According to Terry and Franklin (2000: 97) decision making is the selection of certain behavioral alternatives from two or more existing alternatives. Another opinion is from Hertati (2016) which states that decision making is a process used to choose an action as a way of solving problems. This is in line with the opinion of Hertati (2015) which says that decision making is a process of identifying as many alternatives as possible and choosing one alternative that has a probability of success or effectiveness and which is in accordance with the objectives, desires, lifestyle, values, chill. Based on the above studies it can be said that managerial decision making specifically related to the outcome (outcome) of decision making in conditions of uncertainty and doubt can be measured using: (Schwalbe (2010), Teale et al. (2003), Suryadi (2007), J Salusu (1996), Simon (1986)

1) Event (problem or event) occurs is an event that is real, actually happens but is not bound by time. In other words, a factual event could have happened in the past or present

2) Act (measures) that include measures are seen as behavior that is formed by the perpetrators in lieu of the response of human actions to produce different characters as a result of the form of the process of interaction in itself. To act an individual must know in advance what he wants. An individual must try to determine his goals, describe the direction of his behavior, estimate the actions of others, check himself and describe what is done by other factors.

3) Outcome / Pay off, is covering a business, profit is king. Profit is defined as the amount of income minus the amount of expenditure, i.e. the amount of money "earned" by a business during a certain calculation period. Then (break even point is a point where costs or expenses and income are balanced so there are no losses or profits. 
How to Align Management Commitments to the Successful Implementation of Management Accounting Information Systems in Manager Decision Making

Hertati, Safkaur, Simanjuntak

Kaplan (1998) states that management accounting information improves decision making, guides strategy development and evaluates existing strategies, and focuses related efforts to improve organizational performance and to evaluate the contribution and performance of organizational units and members. Furthermore Hansen and Mowen (2007) which states that the main role of management accounting information systems is to provide information that facilitates decision making (A major role of management accounting information systems is to supply information that facilitates decision making). According to Taicu (2009) Management accounting information systems are the main providers of information needed by management to make decisions in companies. Information plays a role in solving management problems, problem solving is the main activity that is often used as a reference for the success and failure of manager's career. This statement is reinforced by the statement of Laudon and Laudon (2008) that problem solving will not be effective without the presence of relevant information.

The importance of relevant information in decision making is stated by Rose in Teale et al. (2003) that decision making is an act of choosing between alternative programs designed to obtain certain results, and a review of relevant information is made guided by explicit criteria. Furthermore according to Chenhall (1986) that the design of management accounting systems, is influenced by information features that are useful for management decision making. From some of the statements above, strengthen the conclusion that the successful application of information systems affects the decision making process as stated by Gul (1994) which states that the management accounting information system is an organizational control mechanism and is an effective tool in providing useful information for Noraizah (2001) that there is a relationship between the four categories of information dimensions namely scope, timeliness, aggregation and integration in the availability of information to managers and how they use that information is very important for the decision making process especially for those at managerial and financial levels.

Other results that are in line are the results of research by Sajady et al. (2008) stated that the application of accounting information systems in companies led to an improvement in the manager's decision making process, internal control, the quality of financial statements in facilitating the company's transaction process. The accounting information system is considered an organizational mechanism which is very important for the effectiveness of decision making and control in the organization. The results of research by Feredon and Mahmoodi (2012) states that there is a significant influence on management accounting information systems based on Decision Support and Business Intelligence on Profitability. Based on the theories as concepts in this study that have been mentioned above and some research results that support the theory, the success of the application of management accounting information systems affects manager's decision making.

Hypothesis 2:

Management Accounting Information Systems in Manager Decision Making on Decision Making

\section{METHOD}

The target population of this study is the managers of related units in Small and Medium Enterprises in Indonesia. Keep in mind the conceptual model shown in Figure 1, the review instrument established by utilizing previous studies. The characteristics of the variable hypothesis were designed using SEM-Lisrel five answers from 1 to 5. The measurement items from the current study consisted of three variables which included emergency scientific findings MC, MAIS and MDC. The research data was collected by sending a questionnaire through the company's e-mail address and then collected from 
How to Align Management Commitments to the Successful Implementation of Management Accounting Information Systems in Manager Decision Making

Hertati, Safkaur, Simanjuntak

a total of one hundred and twenty four Small and Medium Enterprises in Indonesia. Small and Medium Enterprises in Indonesia located throughout Indonesia.

After sending questionnaires to managers for their responses. The process of selecting and knowledge managers is very important for data collection for researchers, when investigating creativity, emphasizes the centralization of employee knowledge that is relevant to the concept of management accounting information systems and thus can provide meaningful responses (Dul et al., 2011). Therefore, a total of six hundred and twenty questionnaires were sent to the relevant sub-units, from which 357 managers responded. Overall, the data collection process has been taken for three months. This research was not funded by any association. Investigation has also followed the rules of Dillman (1978) in considering moral and ethical actions.

Figure 1: Research model

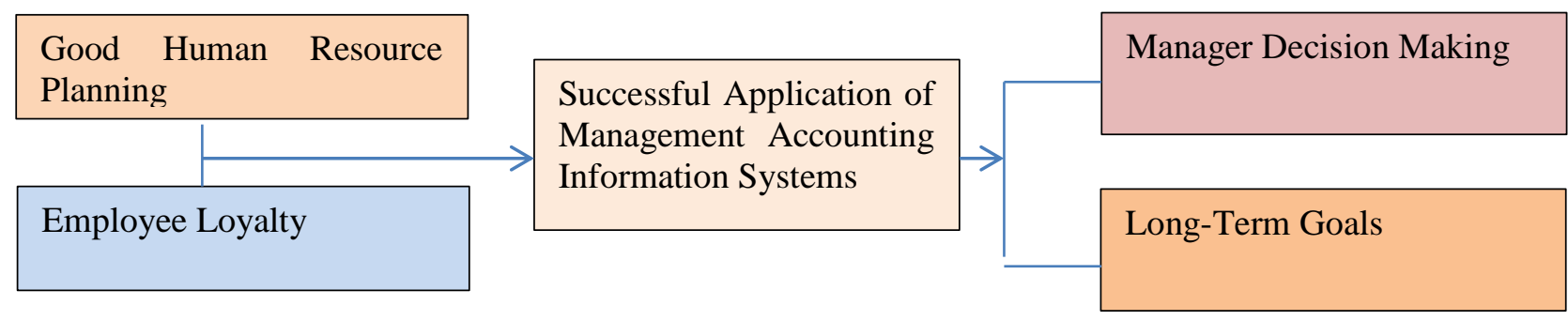

Source: picture of a research framework

\section{RESULTS AND DISCUSSIONS}

Data analysis of this study was completed using SEM Lisrel statistical software. The final valid sample of this study was 357 after testing it was obtained that the data processed were, respectively. Shown in Table 1 is the structure and composition of the data responses used in this study. Thus to test the problem of multicollinearity, the flow of research follows Hair et al. (2014) found that all values in the Pearson Correlation Matrix were $<0.90$. Therefore, confirmation of the absence of multicollinearity among predictors (Hair et al., 2014). This study uses a type of principal component that is highly favored for factoring which brings together a total of 28 questionnaire item-scaled ratios into three final variables. To check for adequacy samples, the Kaiser-Meyer-Olkin value (0.895) indicates that the data is appropriate for making factors because the $\mathrm{KMO}$ value is greater than the cut-off value of 0.7 as suggested by (Barkus et al., 2006). Moreover, the results of the Bartlet Test from the Ball were also found to be significant $(\mathrm{P}<0.05)$, so rejecting the null hypothesis represented the absence of an identity matrix correlation (Afshan et al., 2018). The last seven factors succeeded in defining $78.6 \%$ of the total variance described. The explanation of the rotated component matrix highlights a total of twenty-eight items which show a factor of more than 0.70 and above the 0.55 benchmark as suggested by Tabachnick and Fidell (2007). The results of factor loading for each variable item are shown in Table 1. Furthermore, the samples collected were further examined for convergent validity, reliability and relevance.

Table 1 Evaluation Results of Dimension Relevance Measurement

\begin{tabular}{|l|l|l|l|l|l|l|l|}
\hline Latent & Dimension & Weight & $\begin{array}{l}\text { Defaul } \\
\text { t error }\end{array}$ & $\begin{array}{l}\text { value- } \\
\mathbf{z}\end{array}$ & $\begin{array}{l}\text { Value- } \\
\mathbf{p}\end{array}$ & Sig & Relevant \\
\hline \multirow{2}{*}{$\begin{array}{l}\text { Managemen } \\
\text { t }\end{array}$} & Affective Commitment & 0,19 & 0,011 & 17,12 & 0,000 & Sig & Relevant \\
\cline { 2 - 8 } Commitmen & Continuance Commitment & 0,44 & 0,006 & 78,65 & 0,000 & Sig & Relevant \\
\cline { 2 - 8 } & Normative Commitment & 0,76 & 0,007 & 101,30 & 0,000 & Sig & Relevant \\
\hline
\end{tabular}

97 I Ilomata International Journal of Tax \& Accounting

Vol. 1 No. 2 March 2020 
How to Align Management Commitments to the Successful Implementation of Management Accounting Information Systems in Manager Decision Making

Hertati, Safkaur, Simanjuntak

\begin{tabular}{|l|l|l|l|l|l|l|l|}
\hline $\mathrm{t}$ & & & & & & & \\
\hline \multirow{5}{*}{ MAIS } & $\begin{array}{l}\text { Scope of information } \\
\text { system }\end{array}$ & 0,44 & 0,013 & 33,94 & 0,000 & Sig & Relevant \\
\cline { 2 - 7 } & $\begin{array}{l}\text { Timelines of management } \\
\text { accounting information }\end{array}$ & 0,46 & 0,014 & 33,86 & 0,000 & Sig & Relevant \\
\cline { 2 - 8 } & $\begin{array}{l}\text { Aggregationis Management } \\
\text { accounting may provide } \\
\text { information aggregated }\end{array}$ & 0,45 & 0,013 & 34,25 & 0,000 & Sig & Relevant \\
\cline { 2 - 8 } & $\begin{array}{l}\text { Integrative information is } \\
\text { Integrative information }\end{array}$ & 0,43 & 0,013 & 33,44 & 0,000 & Sig & Relevant \\
\hline \multirow{2}{*}{$\begin{array}{l}\text { Decision- } \\
\text { making }\end{array}$} & Event & 0,40 & 0,017 & 22,67 & 0,000 & Sig & Relevant \\
\cline { 2 - 8 } & Act & 0,45 & 0,017 & 26,32 & 0,000 & Sig & Relevant \\
\cline { 2 - 7 } & Out Come/Pay Off & 0,46 & 0,011 & 39,99 & 0,000 & Sig & Relevant \\
\hline
\end{tabular}

Source: results of calculation of score components with the R program

Based on information obtained from table 1, showing a P-value smaller than 0.5 then all dimensions are relevant as a measurement tool for each variable.

Tabel 2 Parameter Model Struktural

\begin{tabular}{lcccccccc}
\hline $\begin{array}{l}\text { Conse } \\
\text { quenc } \\
\text { e }\end{array}$ & $\begin{array}{l}\text { Mediato } \\
\mathrm{r}\end{array}$ & Cause & $\begin{array}{l}\text { Standard } \\
\text { estimate }\end{array}$ & $\begin{array}{l}\text { Estimate } \\
\mathrm{d}\end{array}$ & $\begin{array}{l}\text { Default } \\
\text { error }\end{array}$ & $\begin{array}{l}\text { Value- } \\
\mathrm{z}\end{array}$ & Value-p & Information \\
\hline MAIS & - & MC & 0,60 & 0,360 & 0,20 & 1,81 & 0,965 & Significant \\
& - & MDC & 0,58 & 0,061 & 0,07 & 1,86 & 0,196 & Significant
\end{tabular}

Source: results of calculation of score components with the R program

Theoretically, the better the management commitment, the better the application of management accounting information systems, this study proves influential. The phenomenon of decision-making quality is not yet high because the application of management accounting information systems has not been able to design management commitments flexibly and integrated accurately and timely in the face of effective commitments, ongoing commitments and normative commitments. The better the application of management accounting information systems the better decision making, this study states influence. The phenomenon of decision-making quality is not yet high because the application of management accounting information systems places human resources that are not in accordance with the expertise that exists in a company, namely the relevance of identity, shared value, personal involvement. The better the application of management accounting information systems, the better the decisions taken by managers. The phenomenon of decision-making quality is not yet high because the application of management accounting information systems is still too late in the completion of problematic work on recording, summarizing and reporting that is not accurate, timely so that it cannot be used as a basis for decision making.

\section{CONCLUSION}

The findings of this study highlight the most important role of management commitment in influencing the application of management accounting information systems. This implies that organizations must consider this management commitment as a measure of threat to the successful 
How to Align Management Commitments to the Successful Implementation of Management Accounting Information Systems in Manager Decision Making

Hertati, Safkaur, Simanjuntak

implementation of management accounting information systems and has the potential to inhibit the successful implementation of management accounting information systems. In this case, the present study proposes managers and human resource experts to assess carefully the possibility of external risks with a diversified approach to organizational dependence on limited options. Furthermore, the importance of successful implementation of management accounting information systems is also highlighted as an important driver of successful implementation of useful management accounting information systems.

This shows that an error in understanding or measuring human resources causes a decrease in the true purpose of management commitment. Therefore, managers are recommended to observe the measurement process in determining the environmental costs and related components to ensure the reliability of data accumulation. An orderly assimilation of organizational data and accurate data is the basis for achieving efficiency and successful application of management accounting information systems. The focal point for the successful implementation of management accounting information systems is on physical natural data, it must also consider how this data can be coordinated with company measurements and thus empower more important scope in providing benefits to organizations, and government. Finally, this research also calls for the need to maintain quality if the commitment of management by placing people who are experts in their fields so that they work according to their expertise, good human resources have the skills, abilities will encourage healthy companies to lead in the future.

\section{ACKNOWLEDGEMENT}

We would like to thank our colleagues and related units from Indonesian MSMEs who were willing to be interviewed and filled out the questionnaire well and provided insights and expertise that greatly assisted this research, even though they might not agree with all interpretations / conclusions from this paper.

\section{REFERENCES}

Abrahamsson, Pekka \& Iivari, Netta. (2002). Commitment in Software Process Improvement. Proceedings of the 35th Hawaii International Conference on System Sciences.

Abrahamsson, Pekka \& Jokela, Timo. (2000). Development of Management Commitment to Software Process Improvement. Proceedings of IRIS 23. Laboratorium for Interaction Technology, University of Trollhättan Uddevalla.

Afshan, S., Sharif, A. (2016), Acceptance of mobile banking framework in Pakistan. Telematics and Informatics, 33(2), 370-387.

Afshan, S., Sharif, A., Waseem, N., Frooghi, R. (2018), Internet banking in Pakistan: An extended technology acceptance perspective. International Journal of Business Information Systems, 27(3), 383-410.

Ashfaq, Ahmad. 2007. Making Management Commitment Happen in Software Process Improvement Department of Applied Information Technology. Report no. 2007: 116 ISSN: 1651-4769 Göteborg, Sweden

Atkinson, Anthony A. et al. dialihbahasakan oleh Miranti Kartika. 2009. Akuntansi Manajemen. Edisi kelima. PT. INDEKS

Barkus, E., Yavorsky, C., Foster, J. (2006), Understanding and Using Advanced Statistics. Faculty of Health and Behavioural Sciences Papers, No. 393.

Brah, S.A., Serene T.S.L. and Rao, B.M. 2002. Relationship Between TQM and Performance of Singapore Companies. International Journal of Quality and Reliability Management, Vol 19, No. 4, hal 356-379. 
How to Align Management Commitments to the Successful Implementation of Management Accounting Information Systems in Manager Decision Making

Hertati, Safkaur, Simanjuntak

Bhanu, S. Ragu- Nathan, Charles H. Apigiah, T.S. Ragu-Nathan, Qiang Tu. 2004. A Path Analytic Study of The Effect of Top Management Support for Information System Performance. The International Journal of Management Science. Omega 32.

Chalk, David N. 2008. Management by Commitment. Author House Bloomington, Indiana

Chenhall, R., Morris, D. 1986. The impact of structure, environment, and interdependence on the perceived usefulness of management accounting systems. The Accounting Review January. p.16-35.

Chen, I. 2001. Planning for ERP Systems: Analysis and Future Trend. Business Process

Management Journal. (7:5), , pp. $374-386$

Cooper, Dominic. 2006. The Impacts Management Commitment on Employee Behaviour : A Field Study.

Profesional Development Conference and Exhibition. March 18- 22. 2006

DeLone W and E. McLean. 1992. Information Systems Success: The Quest for the Dependent Variable. Information Systems Research. 3(1), 1992, pp. 60-95.

Dillman, D.A. (1978), Mail and Telephone Surveys: The Total Design Method. Vol. 19. New York: Wiley.

Dul, J., Ceylan, C., Jaspers, F. (2011), Knowledge workers' creativity and the role of the physical work environment. Human Resource Management, 50(6), 715-734.

Esteves., Jose.,Pastor Joan., Casanovas, Josep. 2002. Measuring Sustained Management Support in ERP Implementation projects : A GQM Approach. Communication of Association for Information System. ( Volume 9 ; 2002) 334-355

Feredon, Hashem and Mohammad Mahmoodi. 2012. The Effect of Management Accounting Information System Based on Decision Support and Business Intelligence in Profitability. American Journal of Scientific Research ISSN 1450- 223X Issue 51 (2012), pp. 86-93 C Euro Journals Publishing, Inc

Gelinas Jr, Ulric J \& Dull, Richard B. 2008. Accounting Information System. 7th edition. Thomson South Western. USA.

Gul, F.A., Chia, Y.M. 1994. The Effects of Management Accounting Systems, Perceived Environmental Uncertainty and Decentralization on Managerial Performance. A Test of Three-Way Interaction, Accounting, Organization and Society, Vol 19, No. 4/5.pp 413-426.

Hall, James A. 2011. Accounting Information Systems. Seventh Edition. Cengage Learning 5191 Natorp Boulevard Mason, OH 45040 USA

Hair.Jr.J.F.Hult.G.T.M., Ringle, C.M \& Sarted.,M 2014 A Primer on Partial Least Squares Structural Equation Modeling (PLS-SEM). Califrnia : sage Publication, Inc

Harris, Robert. 2009. Introduction to Decision Making. Melalui : <http://www.virtualsalt. com/bioblurb.htm.> (09/11/12)

Hansen, D.R. \& Mowen, M.M.2007. Managerial Accounting, Eighth Edition. Mason: Thomson SounthWestern.

Hertati. L 2015. Competence of Human Resources, The Benefits of Information Technology on Value of Financial Reporting in Indonesia. Research Journal of Finance and Accounting www.iiste.org.ISSN 2222-1697 (Paper) ISSN 2222-2847 (Online) Vol.6, No.8, 2015

Hertati.L.2015. Impact of uncertainty of environment and organizational cultural on accounting information system management and implications for managerial performance proposing a conceptual framework. International Journal of Economics, Commerce and Management United Kingdom Vol. III, Issue 12, December 2015 Licensed under Creative Common Page 455 http://ijecm.co.uk/ ISSN 23480386

Hertati.L. 2015. Total Quality Management As Technics On Strategic Management Accounting. International Journal of Recent Advances in Multidisciplinary Research Vol. 02, Issue 11, pp.09420949, November, 2015

Hertati, L.2015. Internal Control And Ethics Of Quality Management System Accounting Information And Implications On The Quality Of Accounting Information Management: Proposing A Research Framework. International Journal of Economics, Commerce and Management United Kingdom Vol. III, Issue 6, June 2015 Licensed under Creative Common Page 902 http://ijecm.co.uk/ ISSN 23480386

91 | Ilomata International Journal of Tax \& Accounting

Vol. 1 No. 2 March 2020 
How to Align Management Commitments to the Successful Implementation of Management Accounting Information Systems in Manager Decision Making

Hertati, Safkaur, Simanjuntak

Hertati.L. 2016. Just In Time, Value Chain, Total Quality Management, Part Of Technical Strategic Management Accounting. International Journal Of Scientific \& Technology Research Volume 5, Issue 04, April 2016 Issn 2277-8616

Hertati, and Sumantri 2016. Just In Time, Value Chain, Total Quality Management, Part Of Technical Strategic Management Accounting.International Journal Of Scientific \& Technology Research Volume 5, Issue 04, April 2016 Issn 2277-8616.

Hertati.L. 2019. The Effect of Human Resource Ethics on Financial Reporting Implications for Good Government Governance (Survey of Related Sub-units in State-owned Enterprises in SUMSEL). International Journal of Economics and Financial Issues ISSN: 2146-4138 available at http: www.econjournals.com International Journal of Economics and Financial Issues, 2019, 9(4), 267 276

Horngren, C.T, datar, S.M. \& Rajan, M.V. 2017. Cost Acounting : A Managerial Emphasis, Fifteenth Edition. New Jersey: Pearson Education, Inc.

Horngren, Sundem, Straton, Burgstahler, Schatzberg. 2011. Introduction To Management Accounting 15thedition. Prentice Hall International Inc

Intermezzo 2019.10 Permasalahan UKM dan Cara Mudah untuk Mengatasinya. https://interactive.co.id/blog/ 10-permasalahan-ukm-dan-cara-mudah-untuk-mengatasinya127.html

J. Salusu. 1996. Pengambilan Keputusan Strategik, Gramedia Widiasarana. Jakarta.

Kreitner, Robert and Kinichi, Angelo. 2001. Organizational Behavior. Fifth edition. Irwin McGraw-Hill.

Kırmız1, Abdulkadir and Orkun Deniz. 2009. The Organizational Commitment of Information Technology Professionals in Private Banks. European and Mediterranean Conference on Information Systems

Laudon, K.C. \& Laudon, J.P. 2008. Management Information Systems. 10th Edition. Prentice-Hall. Inc. New Jersey

Larsen, Kai .R.T. 2003. A Taxonomy of Antecedents of Information Systems Implementation: Variable Analysis Studies. Journal of Management Information Systems. 20(2): 169-246.

Luthan, Fred. 2006. Organizational Behavior, 10th edition, McGraw-Hill International Ed, Singapore.

Pabedinskaite, Arnoldina. 2010. Factors of Successfull Implementation of ERP System. Economics and Managements

Robbins, Stephen, P., and A Judge Timothy. 2008. Perilaku organisasi (Organizational Behavior) 12th edition Salemba empat

Sajady, M. Dastgir, and Hashem Nejad, M. S. 2008. Evaluation Of The Effectiveness Of Accounting Information Systems. International Journal of Information Science and Technology

Sharma, Rajeev and Yetton, Philip. 2003. The Contingent Effect of Management Support and Task Interdependence on Succeeful Information System Implementation. MIS Quartely. Vol. 27 No. 4.

Susanto. 2016. What Factors Influence The Quality Of Accounting Information. I J A B E R, Vol. 14, No. 3, (2016): 2263-2280

Susanto. 2016. The influence of Accounting Information System Quality to Accounting Information Quality and its Implication to the Good Study of Governance Programs International Business Management 10 (24): 5767-5776,2016 ISSN: 1993-5250 Medwel Journl, 2016

Susanto. 2016.The Effect of Internal control and Accounting Information System. 10 (243): 55235529,2016 ISSN: 1993-5250 medwel Journl, 2016 Medwel Journl, 2016

Susanto. 2008. Sistem Informasi Akuntansi. Lingga Jaya. Bandung Malthis, Robert L and Jackson, John H. 2008. Human Resources Management 12thedition. Thomson South Western

Taicu, Marian. 2009. Ethic in Management Accounting.Scientific Bulletin-Economic

Science Vol 9 .

Teale, Mark., Vincen D, David C. Flynn John. 2003. Management decision making, towards an Integrative Approach. Prentice Hall

Meilani, M., \& Pandoyo, P. (2019). The Influence of Account Receivable for Inventory of Income before Tax. Ilomata International Journal of Tax and Accounting, 1(1), 35-40. 
How to Align Management Commitments to the Successful Implementation of Management Accounting Information Systems in Manager Decision Making

Hertati, Safkaur, Simanjuntak

Meyer, J. P.,\& Allen, N.J. 1997. Commitment in the workplace: Theory, research, and application. Newbury Park, CA: Sage.

Meyer J. P and Herscovitch L. 2001. Commitment in the Workplace: Toward a General Model. Human Resource Management Review. Vol. 11

Meyer, John P., David J. Stanley., Lynne Herscovitch, Laryssa and Topolnytsky 2002. Affective, Continuance, and Normative Commitment to the Organization: A Metaanalysis of Antecedents, Correlates, and Consequences. Journal of Vocational Behavior no. 61, 20-52

Meyer, J. P.,\& Allen, N.J. 1997. Commitment in the workplace: Theory, research, and application. Newbury Park, CA: Sage.

McLeod, R. \& Schell, G. 2007. Management Information Systems. 9thEdition. Prentice- Hall. Inc. New Jersey

Mitchell, F. Reid, G., and Smith J. 2000. Information System Development in the Small Firm : The use of management accounting. CIMA Publishing

Noraizah, Abu Bakar. 2001. The Availability of Management Accounting Information and its Usefulness to Managers in the Manufacturing Sector. Journal of Accountancy, UiTM

Taicu, Marian. 2009. Ethic in Management Accounting.Scientific Bulletin-Economic Science Vol 9 .

Tabachnick, B.G., Fidell, L.S. (2007), Using Multivariate Statistics. Boston, MA: Allyn and Bacon/Pearson Education.

Wood, Stephen. 1996. High commitment management and organization in the UK. The International Journal of Human Resource Management. pp 41-58

Yousaf, Nadeem. 2006. Top Management Commitment For TQM - A Process Model. Pakistan's 10th International Convention on Quality Improvement ICQI 